\title{
Determining fair value and maximum price in corporate acquisition (case study: Palm Oil Industry)
}

\author{
I K Gunarta ${ }^{1 *}$, G. Alexander ${ }^{2}$, \\ ${ }^{1,2}$ Department of Industrial Engineering, Institut Teknologi Sepuluh Nopember, \\ Kampus ITS Sukolilo-Surabaya 60111, Indonesia \\ *ik.gunarta@gmail.com
}

\begin{abstract}
Acquisition is an act of taking over, in which negotiation may occur. Acquirer values target to determine the purchase price, based on existing condition of the target. This paper values the target with income approach on perspective of the acquirer. The approach applies financial model, estimating future income and cost of the target unto defined period. Net Present Value in free cash flow through the end of projected year is reflected as target value. On the other hand, maximum price acts as regards of the acquirer to point out the highest amount it could afford, yet still attaining positive return from the acquisition. This valuation is conducted in palm oil industry. Thus, the income and cost estimated are in regards to income and cost from oil palm plantation and palm oil mill. Value of the target is Rp. 249,518,452,138.67. The maximum purchase price applies similar cash flow to valuation, in addition to the expected purchase price in outflow component. Internal Rate of Return generated from this cash flow, in which is slightly above the required return, has the price as the maximum purchase price. It is accounted at Rp. 220,726,834,579.33.
\end{abstract}

\section{Introduction}

Palm oil is applied in industries namely cosmetics, daily essentials, detergent, food and fuel. The consumption of products in these industries is linear to population; increase in population would likely to be followed with increase of the products' consumption. Indonesia and Malaysia are the world's largest palm oil producers and exporters. Both significantly outnumber other countries. Data shown in Index Mundi has Indonesia and Malaysia produced 35,000,000 and 20,000,000 million tons respectively in 2016, whereas their exports are accounted at 26,000,000 and 17,500,000 million tons respectively. Either the third largest palm oil producer or exporter has far less amount than these countries, recorded at 2,3000,000 and 580,000 million tons respectively.

The significance of Indonesia in palm oil industry can be reflected through oil palm plantation area, consumption and ending stock of palm oil. Total area of oil palm plantation in Indonesia kept increasing until 2016. Index Mundi shows the growth of about 3,964,000 hectares of the plantation from previous total area, marked at 5,236,000 hectares in 2006. Oil palm plantation is vital to palm oil as it produces Fresh Fruit Bunches (FFBs), raw material of palm oil. On the other hand, more than half of its production is exported, whereas the remaining is consumed domestically. This consumption shows an overall inclining trend from 2006 to 2016. It dropped in 2014, yet continued to incline in years later. On the contrary, ending stock of palm oil in Indonesia kept declining from 2014 to 2016. This trend is also occurred in 2006 to 2008, yet the number increased until 2013. The condition of increasing in total area 
of oil palm plantation, whereas the ending stock kept declining, shows greater margin in demand meeting its supply. Such condition implies great opportunity for investment in this industry.

This opportunity is given through acquisition of PT. X, company owning oil palm plantation and palm oil mill. According to Kumar (1), acquisition could mean as acquisition of control leading to takeover or acquisition of tangible assets, rights, and other kinds of obligation. According to Miller and Segall (2), acquisition is categorized as friendly acquisition, which applies due diligence and negotiates price and other deal terms, and hostile acquisition, which presents direct tender offer to shareholders, rather than negotiate with target board. The acquisition is performed in friendly manner, which both target and the acquirer, PT. Y, later determine fair value. The need of estimating the value of PT. X is essential, as it helps the acquirer to acknowledge bidding range and return it could attain. This valuation, conducted based on the acquirer's perspective, is applied within income approach. Laro and Pratt (3) said that income approach is conducted with the appliance of the discounted cash flow method or singleperiod capitalization method, which is appeared to be the most common method. This paper applies the discounted cash flow method. It is conducted through financial model that estimates future production of FFBs from its oil palm plantation, FFBs processed in oil palm mill, palm oil and costs exist along the projection period (2017-2027). Net Present Value (NPV) from free cash flow of this model reflects the value of PT. X. Moreover, this acquisition is an investment that should deliver positive return, which is the underlying reason to acknowledge the maximum price. In addition to the expected purchase price of the target, Internal Rate of Return (IRR) resulted from the free cash flow notifies the amount which allows the acquisition to result in positive return.

\section{Research Methodology}

There are several stages occurred in this research. The first is problem identification and objective setting stage. The problem identified is determining fair value of the target and maximum purchase price for this acquisition, whereas the objectives are constructing financial model, estimating the value of the target and determining the maximum purchase amount. The second stage is literature and field study stage. This stage provides knowledge in regards to the conduct of valuation, namely income approach valuation, oil palm and its industry, financial modelling, Discounted Cash Flow (DCF), Weighted Average Cost of Capital (WACC), Free Cash Flow (FCF), Net Present Value (NPV) and Internal Rate of Return (IRR). Field study in regards to the existing oil palm plantation and mill of the target is also appear in this stage, as it describes the business process of both oil palm plantation and palm oil mill of the target. The third stage is data collection, consists of internal data and external data. Internal data includes financial report on previous period, historical data of the target's business operation and both income and cost structure of the target. External data consists of data obtained from due diligence and macroeconomics data. The next stage is data processing, resulting in both target's value and maximum purchase price. The value is obtained through financial model that estimates income and cost structure of the target until 2027, the end of projection period. Future income is estimated with calculation on future production of target's oil palm plantation and palm oil. The cost structure follows the components appeared in previous record. As cash flow unto 2027 has been identified, addition of expected purchase price would generate IRR that later is compared to the required return by the acquirer, in which the rate is WACC of the acquirer. The maximum purchase price lies in the expected amount of purchase price that generates IRR slightly above the required return of the acquirer.

\section{Interpretation and Discussion}

The target value is generated from numbers put into financial model. These numbers are obtained from data collection. The construction of financial model begins with assumptions set from this data. The model would first estimate production of FFBs from the plantation and FFBs purchased from plasma and third party. This amount is as an input for future production of palm oil. Future income of target unto projection year of 2027 is estimated by multiplying this volume with the price of commodity. In regards to cost, the components follow the historical data. Later, target value can be generated from free cash flow, following amount and components occurred in the model. Finally, the maximum purchase 
price can be attained with the exact free cash flow, in addition to expected purchase price in the outflow component.

\subsection{FFBs Production}

Future production of FFBs is estimated with reference on standard production, which Indonesian Oil Palm Research Institute (IOPRI) conducts its research. This reference states the annual standard production of FFBs resulted in one hectare. The production of FFBs is affected by the growth of oil palm. According to Pahan (4) there are three factors affecting the growth, namely innate, induced and enforce. Innate classifies factors derived from the genetics of the plantation. Induced categorizes factors in regards to the management or treatment of the plantation. Enforce is other unexpected factors that affect the growth of plantation, for instance, natural disaster. Aside from these factors, the production of FFBs is classified based on its age and land suitability. Oil palm produces different amount of FFBs throughout its lifetime, whereas the land suitability determines either lower or higher production. This illustration can be seen through table 1 .

Table 1. IOPRI Standard Production of FFBs

\begin{tabular}{cccc}
\hline \multirow{2}{*}{ Age (Year) } & $\begin{array}{c}\text { S1 } \\
\text { FFBs (Ton) }\end{array}$ & $\begin{array}{c}\text { S2 } \\
\text { FFBs (Ton) }\end{array}$ & $\begin{array}{c}\text { S3 } \\
\text { FFBs (Ton) }\end{array}$ \\
\hline 3 & 9 & 7 & 6 \\
4 & 15 & 14 & 12 \\
5 & 18 & 16 & 15 \\
6 & 21 & 19 & 17 \\
7 & 26 & 23 & 22 \\
8 & 30 & 24 & 25 \\
9 & 31 & 28 & 26 \\
10 & 31 & 28 & 26 \\
11 & 31 & 28 & 26 \\
12 & 31 & 28 & 26 \\
13 & 31 & 28 & 26 \\
14 & 30 & 27 & 25 \\
15 & 28 & 26 & 25 \\
16 & 27 & 26 & 24 \\
17 & 26 & 25 & 22 \\
18 & 25 & 24 & 21 \\
19 & 23 & 23 & 20 \\
20 & 24 & 22 & 19 \\
21 & 22 & 21 & 18 \\
22 & 20 & 19 & 17 \\
23 & 19 & 18 & 16 \\
24 & 18 & 17 & 15 \\
25 & 17 & 16 & 14 \\
\hline
\end{tabular}

Land suitability of S1 shows the highest rate of production whereas S3 shows the lowest. The production of FFBs, in classification of its age, has a faced down curve with peak ranges from age of 9 to 13 years. This curve is similar among classes of land suitability.

Future production of FFBs from target's oil palm plantation is computed through existing area of plantation, classified in each planting year, and records of past production. It follows existing condition of the plantation. Historical data in past production, in comparison to the standard production would result in rate of future production. This rate is differed by planting year. As there are 6 planting years in target's plantation, 6 rates of future production occurred. Each rate is later multiplied with its planting year area and standard production. The rate of future production (performance) is obtained by dividing 
the actual production with the standard production based on its age and land suitability. The actual production is obtained from historical data whereas table 1 shows the standard production of FFBs per hectare per year. The estimated production of FFBs from target's plantation in one-year period can be seen in table 2.

Table 2. Estimation on FFBs Production of Target's Plantation

\begin{tabular}{ccccccccc}
\hline \multirow{2}{*}{$\begin{array}{c}\text { Plantation } \\
\text { Year }\end{array}$} & \multirow{2}{*}{$\begin{array}{c}\text { Area } \\
(\mathrm{Ha})\end{array}$} & Performance & Age & $\begin{array}{c}\text { Standard } \\
(\mathrm{Kg})\end{array}$ & Total $(\mathrm{Kg})$ & Age & $\begin{array}{c}\text { Standard } \\
(\mathrm{Kg})\end{array}$ & Total $(\mathrm{Kg})$ \\
\hline 2004 & 799.88 & $59.72 \%$ & 13 & 26,000 & $12,419,440$ & 23 & 16,000 & $7,642,733$ \\
2005 & 1492.31 & $37.53 \%$ & 12 & 26,000 & $14,561,397$ & 22 & 17,000 & $9,520,913$ \\
2006 & 1793.14 & $16.34 \%$ & 11 & 26,000 & $7,617,209$ & 21 & 18,000 & $5,273,453$ \\
2007 & 1164.66 & $10.54 \%$ & 10 & 26,000 & $3,191,421$ & 20 & 19,000 & $2,332,192$ \\
2008 & 1125.12 & $9.55 \%$ & 9 & 26,000 & $2,794,480$ & 19 & 20,000 & $2,149,600$ \\
2009 & 152.48 & $4.64 \%$ & 8 & 24,500 & 173,466 & 18 & 21,000 & 148,685 \\
\hline \multicolumn{2}{l}{ Total Annual Production } & & & $40,757,414$ & & & $27,067,576$ \\
\hline
\end{tabular}

The total amount of FFBs produced in a year by the plantation is the sum of all FFBs from 6 planting years. The amount of FFBs is classified into each planting year, as the amount and performance of FFBs' production in each are different. FFBs produced from plasma undergo similar estimation with the plantation. Table 3 shows the illustration of plasma's estimated FFBs production.

Table 3. Estimation on FFBs Production of Plasma

\begin{tabular}{ccccccccc}
\hline \multirow{2}{*}{$\begin{array}{c}\text { Plantation } \\
\text { Year }\end{array}$} & Area (Ha) & Performance & Age & $\begin{array}{c}\text { Standard } \\
(\mathrm{Kg})\end{array}$ & Total (Kg) & Age & $\begin{array}{c}\text { Standard } \\
(\mathrm{Kg})\end{array}$ & $\begin{array}{c}\text { Total } \\
(\mathrm{Kg})\end{array}$ \\
\hline 2008 & 256.08 & $9.55 \%$ & 9 & 26,000 & 636,030 & 19 & 20,000 & 489,254 \\
2009 & 182.31 & $4.64 \%$ & 8 & 24,500 & 207,402 & 18 & 21,000 & 177,773 \\
\hline \multicolumn{2}{r}{ Total Annual Production } & & & 843,432 & & 667,027 \\
\hline
\end{tabular}

\subsection{Palm Oil Production}

Palm oil mill processes FFBs from target's plantation, plasma and third party. As FFBs production from both target's plantation and plasma has been estimated, the estimation of FFBs from third party puts the amount of remaining capacity of FFBs to be processed as its value. In regards to raw material cost (FFBs cost), the volume of palm oil produced is classified per planting year and origin of the FFBs. Through the exact FFBs, the extraction process would result in two kinds of palm oil, namely Crude Palm Oil (CPO) and Palm Kernel Oil (PKO). The volume of oil generated from the process is obtained by multiplying extraction rates of those kinds of palm oil with FFBs processed, classified as previously defined. These rates are obtained from historical data of target. The total amount of both kinds of palm oil is the sum of all volumes in planting years and origin. The estimation of palm oil production is illustrated in table 4 .

Table 4. Estimation on Palm Oil

\begin{tabular}{lcc}
\hline \multirow{2}{*}{ Details } & \multicolumn{2}{c}{ Year } \\
\cline { 2 - 3 } FFBs Production & 2017 & 2027 \\
\hline Home grown & $40,757,414$ & $27,067,576$ \\
Plasma & 843,432 & 667,027 \\
Third Party Purchase & $94,917,153$ & $108,783,395$ \\
FFBs to be processed & $136,517,999$ & $136,517,999$ \\
\hline Palm Oil Mill Profile & \\
\hline Running Capacity & $136,517,999$ & $136,517,999$ \\
\hline Extraction Rate & \\
\hline
\end{tabular}




\begin{tabular}{|c|c|c|}
\hline \multirow{2}{*}{ Details } & \multicolumn{2}{|c|}{ Year } \\
\hline & 2017 & 2027 \\
\hline OER & $19.01 \%$ & $19.01 \%$ \\
\hline KER & $5.26 \%$ & $5.26 \%$ \\
\hline \multicolumn{3}{|l|}{ Oils Processed } \\
\hline \multicolumn{3}{|l|}{ Home Grown (OER) } \\
\hline 2004 & 2,360,936 & $1,452,883$ \\
\hline 2005 & 2,768,122 & $1,809,926$ \\
\hline 2006 & 1,448,032 & $1,002,483$ \\
\hline 2007 & 606,689 & 443,350 \\
\hline 2008 & 531,231 & 408,639 \\
\hline 2009 & 32,976 & 28,265 \\
\hline Plasma (OER) & 160,336 & 126,802 \\
\hline $\begin{array}{l}\text { Third Party Purchase } \\
\text { (OER) }\end{array}$ & $18,043,751$ & $20,679,723$ \\
\hline $\begin{array}{l}\text { TOTAL CPO } \\
\text { Production } \\
\end{array}$ & $25,952,072$ & $25,952,072$ \\
\hline \multicolumn{3}{|l|}{ Home Grown (KER) } \\
\hline 2004 & 653,263 & 402,008 \\
\hline 2005 & 765,929 & 500,800 \\
\hline 2006 & 400,665 & 277,384 \\
\hline 2007 & 167,869 & 122,673 \\
\hline 2008 & 146,990 & 113,069 \\
\hline 2009 & 9,124 & 7,821 \\
\hline Plasma (KER) & 44,365 & 35,086 \\
\hline $\begin{array}{l}\text { Third Party Purchase } \\
\text { (KER) }\end{array}$ & 4,992,642 & $5,722,007$ \\
\hline $\begin{array}{l}\text { TOTAL PKO } \\
\text { Production }\end{array}$ & 7,180,847 & $7,180,847$ \\
\hline
\end{tabular}

\subsection{Income and Cost Estimation}

Income structure of the target is the revenue from palm oil. The estimation of income amount is sum of $\mathrm{CPO}$ and PKO price, each multiplied by the volume. Components of cost structure are obtained from historical data of the target. The structure can be classified into three, namely raw material, processing and operating expense. Raw material cost is FFBs' cost, in which is differentiated by the origin of FFBs to be processed in palm oil mill. Raw material cost of both plasma and third party is the purchased price of FFBs, whereas the plantation has its field cost as the cost. Main components in field cost are fertilization, harvesting, plantation general administration, upkeep and maintenance. On the other hand, main components in processing cost consist of labour, chemical, processing and factory overhead. The last is operating expense, which consists of selling expense, general and administrative expense.

Raw material cost from plasma and third party is estimated by multiplying the volume of FFBs with FFB's price exists in each origin. On the other hand, estimation on raw material cost from the plantation requires historical data of its field cost. Cost in either per unit of hectare or FFBs produced is identified from historical data, in which this amount is multiplied by existing total area or FFBs produced. This estimation can be seen in table 5 . 
Table 5. Raw Material (FFBs) Cost

\begin{tabular}{lcc}
\hline \multirow{2}{*}{ Details } & \multicolumn{2}{c}{ Year } \\
\cline { 2 - 3 } & 2017 & 2027 \\
\hline Mature Hectare & 6527.59 & 6527.59 \\
FFBs from Home Grown & $40,757,414.22$ & 27067576.38 \\
\hline \multicolumn{1}{c}{ FFB Cost } & & \\
\hline \multicolumn{1}{c}{ Field Cost } & $51,533,512,661$ & $54,377,276,404$ \\
Upkeep & $10,919,732,395$ & $13,311,092,857$ \\
Fertilization & $3,404,633,910$ & $4,150,229,739$ \\
Harvesting & $15,609,463,075$ & $12,725,571,918$ \\
Plantation General & $21,599,683,281$ & $24,190,381,890$ \\
Administration & & \\
$\quad$ FFBs Purchased & $1,480,216,449$ & $1,426,987,816$ \\
Plasma & $166,578,805,458$ & $232,723,033,998$ \\
Purchased &
\end{tabular}

Processing cost has similar amount per kg unit of oil among origins. It is estimated by determining the proportion of each component from the overall total cost. This proportion, obtained through historical data. Components in processing cost are categorized into joint cost and separable cost. Joint cost has components in which both kinds of oil undergo the process, whereas separable cost is cost occurred in process, which only occurs in each commodity. Clarification and Kernel are the processes that only be undergone by CPO and PKO respectively. Processing cost is estimated by multiplying total unit cost per kg of oil with total volume of CPO and PKO. Cost of each component can be acquired by multiplying its proportion with the total cost. Processing cost of CPO is estimated by summing joint cost with clarification cost, whereas processing cost of PKO is estimated by summing joint cost with kernel cost. Estimation on processing cost is illustrated in table 6.

Table 6. Estimation on Processing Cost

\begin{tabular}{lccc}
\hline \multirow{2}{*}{ Component } & \multirow{2}{*}{ Proportion } & \multicolumn{2}{c}{ Year } \\
\cline { 3 - 4 } \multicolumn{1}{c}{ Labour } & & 2017 & 2027 \\
\hline Chemical & $19.21 \%$ & $2,766,141,758$ & $3,371,911,368$ \\
Processing Overhead & $0.62 \%$ & $89,841,795$ & $109,516,647$ \\
\hline Stations & $37.71 \%$ & $5,428,376,238$ & $6,617,160,343$ \\
\hline Small Tools & & & \\
Electricity & $0.00 \%$ & - & - \\
Water Installation & $3.48 \%$ & $501,181,113$ & $610,936,980$ \\
Effluent & $0.62 \%$ & $89,388,128$ & $108,963,630$ \\
Laboratory & $1.71 \%$ & $245,844,205$ & $299,682,714$ \\
Loading & $5.52 \%$ & $794,352,986$ & $968,311,857$ \\
Maintenance & $8.59 \%$ & $1,237,146,293$ & $1,508,074,427$ \\
Reception & $0.23 \%$ & $33,360,091$ & $40,665,765$ \\
Sterilizer & $0.57 \%$ & $82,529,514$ & $100,603,016$
\end{tabular}




\begin{tabular}{lccc}
\hline \multirow{2}{*}{ Component } & \multirow{2}{*}{ Proportion } & \multicolumn{2}{c}{ Year } \\
\cline { 3 - 4 } & & 2017 & 2027 \\
\hline Thresher & $1.31 \%$ & $188,807,717$ & $230,155,554$ \\
Kernel & $1.96 \%$ & $282,025,479$ & $343,787,485$ \\
Pressing & $3.70 \%$ & $532,213,431$ & $648,765,203$ \\
Clarification & $0.82 \%$ & $118,210,060$ & $144,097,403$ \\
\hline Total Processing Cost & $57.54 \%$ & $8,284,359,791$ & $10,098,588,358$ \\
\multicolumn{1}{c}{ Factory Overhead } & $42.46 \%$ & $6,112,555,894$ & $7,451,171,526$ \\
\hline Total Oil Mill Cost & $100.00 \%$ & $14,396,915,685$ & $17,549,759,885$ \\
\hline
\end{tabular}

As raw material and processing cost have been identified, total production cost can be estimated. The total production cost is classified into kinds of oil. The cost of each commodity is shown through the amount of Cost of Goods Sold (COGS). Estimation on the total production cost is described in table 7.

Table 7. Estimation on Production Cost

\begin{tabular}{lcc}
\hline \multirow{2}{*}{ Description } & \multicolumn{2}{c}{ Year } \\
\cline { 2 - 3 } & Volume $(\mathrm{Kg})$ & 2027 \\
\hline CPO & & \\
Production & $25,952,072$ & $25,952,072$ \\
Beginning Inventory & 72,474 & 72,474 \\
Available to Sales & $26,024,545$ & $26,024,545$ \\
Ending Inventory & 72,474 & 72,474 \\
COGS & $25,952,072$ & $25,952,072$ \\
PKO & & \\
Production & $7,180,847$ & $7,180,847$ \\
Beginning Inventory & 56,939 & 56,939 \\
Available to Sales & $7,237,786$ & $7,237,786$ \\
Ending Inventory & 56,939 & 56,939 \\
COGS & $7,180,847$ & $7,180,847$ \\
\hline & Amount $(\mathrm{Rp})$. & \\
\hline CPO & & \\
Beginning Inventory & $468,299,114$ & $701,167,265$ \\
$\quad$ Production Cost & & \\
Raw Material & $197,633,281,111$ & $259,674,568,395$ \\
Processing Cost & $12,715,222,191$ & $15,499,784,900$ \\
$\quad$ Joint Cost & $12,597,012,131$ & $15,355,687,496$ \\
$\quad$ Separable Cost & $118,210,060$ & $144,097,403$ \\
Available to Sales & $210,816,802,417$ & $275,875,520,560$ \\
Ending Inventory & $473,723,055$ & $742,461,074$ \\
COGS & $210,343,079,361$ & $275,133,059,486$ \\
COGS per ton & $8,105,059$ & $10,601,584$ \\
PKO & & \\
Beginning Inventory & $153,544,246$ & $229,378,195$ \\
$\quad$ Production Cost & $21,959,253,457$ & $28,852,729,822$ \\
Raw Material & &
\end{tabular}




\begin{tabular}{lcc}
\hline \multirow{2}{*}{ Description } & \multicolumn{2}{c}{ Year } \\
\cline { 2 - 3 } & 2017 & 2027 \\
\hline Processing Cost & $1,681,693,494$ & $2,049,974,985$ \\
Joint Cost & $1,399,668,015$ & $1,706,187,500$ \\
Separable Cost & $282,025,479$ & $343,787,485$ \\
Available to Sales & $23,794,491,197$ & $31,132,083,002$ \\
Ending Inventory & $154,283,521$ & $242,896,438$ \\
COGS & $23,640,207,675$ & $30,889,186,564$ \\
COGS per ton & $3,292,120$ & $4,301,608$ \\
\hline
\end{tabular}

Production cost of palm oil is divided into origin of FFBs and commodities of finished goods (CPO and PKO). The production cost consists of raw material cost, in which its unit cost differs among origins, and processing cost, which unit cost is similar among the origins. As an example, estimation on production cost occurred in the plantation is illustrated in table 8 .

Table 8. Estimation on Plantation's Production Cost

\begin{tabular}{|c|c|c|}
\hline \multirow{2}{*}{ Description } & \multicolumn{2}{|c|}{ Year } \\
\hline & 2017 & 2027 \\
\hline \multicolumn{3}{|c|}{ Volume (Kg) } \\
\hline \multicolumn{3}{|l|}{ CPO } \\
\hline Production & $7,747,984$ & $5,145,546$ \\
\hline Beginning Inventory & 72,474 & 72,474 \\
\hline Available to Sales & $7,820,458$ & $5,218,020$ \\
\hline Ending Inventory & 72,474 & 72,474 \\
\hline COGS & $7,747,984$ & $5,145,546$ \\
\hline \multicolumn{3}{|l|}{ PKO } \\
\hline Production & $2,143,840$ & $1,423,755$ \\
\hline Beginning Inventory & 56,939 & 56,939 \\
\hline Available to Sales & $2,200,779$ & $1,480,694$ \\
\hline Ending Inventory & 56,939 & 56,939 \\
\hline COGS & $2,143,840$ & $1,423,755$ \\
\hline \multicolumn{3}{|c|}{ Amount (Rp.) } \\
\hline \multicolumn{3}{|l|}{ CPO } \\
\hline Beginning Inventory & $468,299,114$ & 701,167,265 \\
\hline Production & 50,176,287,777 & $52,012,708,455$ \\
\hline Raw Material (90\%) & 46,380,161,395 & 48,939,548,763 \\
\hline Processing Cost (90\%) & 3,796,126,382 & 3,073,159,691 \\
\hline Available to Sales & 50,644,586,891 & $52,713,875,719$ \\
\hline Ending Inventory & 473,723,055 & 742,461,074 \\
\hline COGS & 50,170,863,836 & $51,971,414,646$ \\
\hline \multirow{2}{*}{\multicolumn{3}{|c|}{ PKO }} \\
\hline & & \\
\hline Beginning Inventory & $153,544,246$ & 229,378,195 \\
\hline Production & $5,655,420,435$ & $5,844,178,474$ \\
\hline Raw Material (10\%) & 5,153,351,266 & $5,437,727,640$ \\
\hline Processing Cost (10\%) & $502,069,169$ & $406,450,834$ \\
\hline Available to Sales & $5,808,964,681$ & 6,073,556,669 \\
\hline Ending Inventory & 154,283,521 & $242,896,438$ \\
\hline COGS & $5,654,681,160$ & 5,830,660,231 \\
\hline COGS per kg unit of oil & 2,638 & 4,095 \\
\hline
\end{tabular}


The total cost of operating expense is sum of selling expense and general and administrative expense. General and administrative expense is estimated by multiplying historical data with escalation rate. Selling expense is estimated by multiplying volume of CPO with oil cost per unit of kg in selling expense. Historical records show no cost occurred in regards to selling expense of PKO.

As the income and cost unto the end of projection period have been obtained, in addition to previous financial reports, financial statements of target in the projection period can be identified. Income statement, balance sheet and cash flow of the projection period would enable all components in free cash flow to be identified. This free cash flow model would determine the target value of the target, reflected by NPV.

\subsection{Target Value of PT. $X$}

Target Value can be obtained by modelling the free cash flow unto the end of projection period, with regards previously estimated in the financial model. The free cash flow has inflow components, namely income, depreciation, interest (1-tax) and terminal value, and outflow components, namely changes in working capital. Future values of free cash flow are discounted with WACC of the target. WACC of target is calculated with risk free, market return, beta of the target and debt to equity ratio. It is accounted at $11.08 \%$. Net Present Value from this free cash flow represents the target value, which is accounted at Rp. 249,518,452,138.67. The illustration of free cash flow model is shown in table 9.

Table 9. Free Cash Flow of Target Valuation

\begin{tabular}{|c|c|c|c|}
\hline \multirow{2}{*}{ Components } & \multicolumn{3}{|c|}{ Year } \\
\hline & 2017 & $\ldots$ & 2027 \\
\hline \multicolumn{4}{|c|}{ INFLOW } \\
\hline Net Profit (Loss) & $21,566,592,883$ & $\ldots$ & $10,729,038,063$ \\
\hline Depreciation & $12,681,505,984$ & $\ldots$ & $10,000,613,368$ \\
\hline Interest (1-tax) & - & $\ldots$ & - \\
\hline Terminal Value & & & $96,768,379,804$ \\
\hline Total Inflow & $34,248,098,867$ & $\ldots$ & $117,498,031,236$ \\
\hline \multicolumn{4}{|c|}{ OUTFLOW } \\
\hline $\begin{array}{l}\text { Changes in working } \\
\text { capital }\end{array}$ & - & $\ldots$ & - \\
\hline Total Outflow & - & $\ldots$ & - \\
\hline NET CASH FLOW & $34,248,098,867$ & & $117,498,031,236$ \\
\hline $\begin{array}{c}\text { Discount rate } \\
\text { NPV }\end{array}$ & & $\begin{array}{c}11.09 \% \\
249,518,452,139\end{array}$ & \\
\hline
\end{tabular}

\subsection{Maximum Purchase Price}

Maximum Purchase Price is obtained by the similar free cash flow model for valuation of the target, yet put addition of expected purchase price in the outflow component. IRR generated from this model is later being compared with required return of the acquirer (WACC of the acquirer). Expected purchase price that generates IRR above WACC of the acquirer implies positive return could be attained if the acquisition is agreed upon the amount, and vice versa. As negotiation occurs, possible amount of purchase price is various. Therefore, the maximum amount is essential to be pointed out, in order to ensure positive return can still be attained upon the amount agreed. Within various amount of purchase price, the maximum amount is accounted at Rp. 220,726,834,579.33, which IRR generated is $14.3 \%$, whereas WACC of the acquirer is accounted at $14.28 \%$. IRR generated from each various amount is shown in table 10. 
Table 10. Results of IRR

\begin{tabular}{cc}
\hline Investment & IRR \\
\hline $211,000,000,000.00$ & $15.576 \%$ \\
$212,000,000,000.00$ & $15.440 \%$ \\
$213,000,000,000.00$ & $15.305 \%$ \\
$214,000,000,000.00$ & $15.171 \%$ \\
$215,000,000,000.00$ & $15.039 \%$ \\
$216,000,000,000.00$ & $14.907 \%$ \\
$217,000,000,000.00$ & $14.777 \%$ \\
$218,000,000,000.00$ & $14.648 \%$ \\
$219,000,000,000.00$ & $14.521 \%$ \\
$220,000,000,000.00$ & $14.394 \%$ \\
$220,726,834,579.33$ & $14.30 \%$ \\
$221,000,000,000.00$ & $14.268 \%$ \\
$222,000,000,000.00$ & $14.144 \%$ \\
$223,000,000,000.00$ & $14.020 \%$ \\
$224,000,000,000.00$ & $13.898 \%$ \\
$225,000,000,000.00$ & $13.777 \%$ \\
$226,000,000,000.00$ & $13.656 \%$ \\
$227,000,000,000.00$ & $13.537 \%$ \\
$228,000,000,000.00$ & $13.419 \%$ \\
$229,000,000,000.00$ & $13.301 \%$ \\
$230,000,000,000.00$ & $13.185 \%$ \\
\hline
\end{tabular}

\section{Conclusion}

This paper aims to determine the fair value and maximum price of corporate acquisition. This acquisition is performed with target runs in palm oil industry. Its business operation is in regards to oil palm plantation and palm oil mill. The valuation is conducted in perspective of the acquirer, in which the target value is estimated in approach of its future income. The valuation projects income of the target unto 2027. It applies financial model that estimates future production of FFBs and palm oil with cost components referred to historical data. Target value is reflected by Net Present Value obtained from free cash flow with WACC of the target as the discount rate. This is accounted at Rp. 249,518,452,138.67. The maximum price of target should be afforded by the acquirer is Rp. 220,726,834,579.33, as IRR generated from the free cash flow is only $0.02 \%$ from required return of the acquirer (WACC of the acquirer).

\section{References}

1. Kumar R. Valuation : theories and concepts. London: Academic Press; 2015.

2. Miller EL, Segall LN. Mergers and acquisitions : a step-by-step legal and practical guide +website. Second edition. Hoboken New Jersey: Wiley; 2017.

3. Laro D, Pratt SP. Business valuation and taxes : procedure, law, and perspective. Hoboken, New Jersey. John Wiley \& Sons; 2005. 450 p.

4. Pahan I, Prayugo S, Armando R. Panduan Lengkap Kelapa Sawit : Manajemen Agribisnis Dari Hulu Hingga Hilir. Bogor: Penebar Swadaya; 2007. 